\title{
Poradnictwo prawne i obywatelskie świadczone na odległość dla osób z niepełnosprawnością. Obserwacje z okresu pandemii
}

Aleksandra Różycka

(D) https://orcid.org/0000-0003-4672-9828 Uniwersytet Warszawski 


\title{
Streszczenie
}

Publiczna darmowa usługa poradnictwa obywatelskiego i prawnego została zwirtualizowana jeszcze przed państwowym „lockdownem”, wprowadzonym w związku z pandemią. Było to możliwe dzięki wcześniejszym doświadczeniom i wprowadzonym rok wcześniej zmianom prawnym i organizacyjnym, które umożliwiły od początku roku 2019 świadczenie usług zdalnych dla osób z niepełnosprawnością. Grupa ta początkowo uzyskała możliwość wyboru pomiędzy poradą udzielaną osobiście a usługami świadczonymi przy pomocy różnych środków porozumiewania się na odległość. Następnie w okresie pandemii zdalna forma porad w większości powiatów stałą się jedyną obowiązującą dla wszystkich obywateli. Tym samym osoby z niepełnosprawnością utraciły dodatkowe udogodnienia, polegające na możliwości osobistego spotkania zarówno w lokalu punktu porad, jak i w miejscu zamieszkania, lub w miejscu wyposażonym w odpowiedni sprzęt wspomagający komunikację czy z dostępem do tłumacza języka migowego. W artykule podjęto próbę odpowiedzi na pytanie, czy w tych warunkach możliwe jest wypełnienie roli poradnictwa prawnego i obywatelskiego, biorąc pod uwagę, że problemy beneficjentów mogą być złożone, a indywidualne sytuacje dzieli znaczna odległość od ideału sprawiedliwej ochrony praw i obowiązków zawartego w systemie prawnym. Rozważono także, jakie okoliczności i formy zdalnego poradnictwa sprzyjają zachowaniu należytej jakości społecznej usług poradniczych, która wydaje się warunkować zbliżenie instytucji systemu prawnego i obowiązujących regulacji z konkretną sytuacją osobistą, a w konsekwencji zwiększa szansę na otrzymanie odpowiedniej i wartościowej porady prawnej lub obywatelskiej przez osoby z niepełnosprawnościami.

\section{Słowa kluczowe}

osoby z niepełnosprawnością, pomoc prawna, poradnictwo prawne, poradnictwo obywatelskie, usługi społeczne.

\section{On-line legal and civic counseling for people with disabilities. Pandemic observations}

\begin{abstract}
The public service of citizens and legal advice has been virtualized even before the lockdown had been implemented in response to the pandemic. This was possible due to previous experiences and both legal and organizational changes introduced one year earlier, which enabled the provision of remote services for people with disabilities from the beginning of 2019. This group of citizens was initially given the choice between advice given in person and services provided by various means of distance communication. Later, in time of the pandemic, the remote advice in most of the poviats (regional unit in Poland) became the only one accessible to all the citizens. Thus people with disabilities lost additional conveniences consisting in the possibility of having a personal meeting both at the point of advice and place of residence, in a place provided with appropriate equipment supporting communication or offering an access to a sign language interpreter. This article attempts to answer the question whether, under these conditions, it is possible to fulfill the role of legal and citizens counseling, taking into account that the problems of the beneficiaries may be complex and they are quite distanced from the ideal of fair protection of rights and obligations contained in the legal system. It was also considered what circumstances and forms of remote counseling contribute to maintaining the appropriate social quality of counseling services, which seems to condition nearing the institutions of the legal system and applicable regulations to a specific situation of an individual and its entire context, and consequently increases the chance of receiving adequate and valuable legal or citizens advice by people with disabilities.
\end{abstract}

\section{Keywords}

citizens advice, legal advice, legal aid, people with disabilities, social services. 
$\mathrm{Z}$ asięganie porad w szeroko rozumianych sprawach prawnych i formalnych nie jest potrzebą codzienną. Jednak same problemy natury prawnej domagające się porady każdego roku dotykają średnio około $4-5 \%{ }^{1}$ społeczeństwa (por. Instytut Spraw Publicznych, 2013). Wiele $\mathrm{z}$ nich przekłada się na dobrostan w takich dziedzinach życia codziennego, jak praca, finanse, mienie lub dotyka spraw podstawowych, jak status osobisty i stosunki w rodzinie. Waga przywiązywana do bieżącego rozwiązywania problemów prawnych i formalnych jest niejednokrotnie wymuszona ich charakterem związanym z upływem terminów wymaganych dla zapewnienia uprawnień zainteresowanym. Dlatego w wielu przypadkach nie ma możliwości zawieszenia prowadzenia spraw od strony prawnej, na przykład ze względu na czasowe utrudnienia w zasięgnięciu porad podczas trwania pandemii. Ponadto niektóre z problemów nasilają się jako uboczne skutki walki z kryzysem epidemicznym. Są to trudności z utrzymaniem zatrudnienia wraz z kolejnymi konsekwencjami, jak bezrobocie. Mnożenie problemów prawnych i innego typu, dotyczących tej samej rodziny lub osoby, i częste występowanie ich razem jako całych klastrów, zostało opisane jako efekt św. Mateusza (por. Merton, 1968).

Oczywistym jest, że opóźnienie w spłacie zobowiązań rzutuje następnie na najbardziej podstawowe dziedziny życia jednostki, jak: zamieszkanie, ochrona zdrowia czy codzienne sprawy bytowe. Wpływ niedoboru środków finansowych na wiele płaszczyzn życia jest jasny zarówno dla samych zainteresowanych, jak i przedstawicieli służb pomocowych. Jednak dla obu tych grup może być niezrozumiałe bezpośrednie przełożenie niektórych zagadnień formalnych na wiele dziedzin życia codziennego. Instytucje prawa często nie są czytelne dla osób nieposiadających specjalistycznej wiedzy w tym zakresie. Wiedza potoczna ani intuicja życiowa nie są wystarczające, by podjąć odpowiednie działania zabezpieczające, a także zrealizować je w wymaganym terminie. W ten sposób dobitnym przykładem efektu św. Mateusza stają się często właśnie problemy z komponentem prawnym (Winczorek, 2019), gdy sprawy nierozwiązane lub niezabezpieczone od strony formalnej często rodzą lub utrwalają szereg kolejnych wykluczeń, podczas gdy negatywne skutki mogą wynikać nie tyle z obiektywnie źle rokującej sytuacji osób zainteresowanych, ale z niepodjętych odpowiednich działań formalnych. Najprostszym przykładem jest konieczność dotrzymania terminów dochodzenia swoich praw w sytuacjach, jak odwołanie od decyzji o odmowie wypłaty świadczenia finansowego lub od wypowiedzenia przez pracodawcę umowy o pracę, które to sprawy relatywnie często mogą być rozpatrywane na korzyść zainteresowanych.

Zatem o ile zasięganie porad w sprawach prawnych nie jest codzienną potrzebą obywateli, to istotna pozostaje codzienna dostępność konsultacji odnośnie przełożenia kwestii prawnych i formalnych na ważne dziedziny życia osoby zainteresowanej, w tym

\footnotetext{
${ }^{1}$ Wartość $4-5 \%$ rocznie została wywiedziona w sposób przybliżony. W tym celu posłużyłam się danymi uzyskanymi w badaniach Instytutu Spraw Publicznych, w których 23\% respondentów wskazało, że w ciągu ostatnich 5 lat doświadczyło sytuacji, w której przydatna byłaby pomoc prawna.
} 
w aspekcie możliwości, a także działań koniecznych dla właściwego zapewnienia uprawnień od strony formalnej.

W dobie kryzysu spowodowanego pandemią jeszcze większego znaczenia nabrał więc bieżący dostęp do poradnictwa. W niniejszym tekście podejmuję analizę uwarunkowań efektywności poradnictwa świadczonego osobom z niepełnosprawnościami w okresie pandemii za pośrednictwem metod komunikacji na odległość w kontekście specyfiki instytucji poradnictwa. W tym celu w pierwszej kolejności należy przyjrzeć się obszarom kształtującym te usługi. Na ciągu kilku ostatnich lat będą to: pole regulacyjne, rozwijające się wraz z kolejnymi posunięciami ustawodawcy, pole organizacyjne również z jego cechami okresu pandemii, a także cechy - potrzeby i zasoby - głównych aktorów instytucji poradnictwa: beneficjentów i świadczących porady. Posłużę się opisem sytuacji zebranych w ramach obserwacji uczestniczącej, prowadzonej podczas udzielania porad $\mathrm{z}$ komponentem formalno-prawnym, gdy uczestniczyłam w procesie poradniczym po stronie świadczeniodawcy. Jak wskazują autorzy „Słownika socjologii jakościowej”: „Czasami obserwacja dokonywana jest niejako przy okazji uczestnictwa. W tym wypadku u podstaw uczestnictwa nie leży decyzja odnośnie do prowadzenia badań, natomiast uczestnictwo pozwala na prowadzenie obserwacji” (Konecki, Chomczyński, 2012, s. 195). Sposobność obserwacji miałam podczas spotkań z mieszkańcami jednej z warszawskich dzielnic w ramach społecznej, a następnie zawodowej, działalności na rzecz samorządu miasta od 2000 do 2017 r., w szczególności w trzech ostatnich latach.

Wykorzystam także dane liczbowe o świadczeniu publicznej usługi nieodpłatnego poradnictwa prawnego i obywatelskiego w okresie pandemii, udostępniane przez resort sprawiedliwości, w którego dziale administracji publicznej znajdują się usługi omawianego poradnictwa.

Przez poradnictwo na potrzeby tego artykułu rozumiane są dwie usługi: 1. poradnictwo prawne, którego zadaniem jest wsparcie w rozwiązywaniu problemów prawnych na etapie pozasądowym oraz 2. poradnictwo obywatelskie, którego rolą jest wsparcie w rozwiązaniu problemów, które obok innych dziedzin życia dotykają kwestii prawnych. Przy czym poradnictwo obywatelskie ma zastosowanie, jeśli osadzenie danej sprawy na gruncie regulacji prawnych wymaga dopełnienia określonych formalności, jednak niekoniecznie wysoce złożonych od strony prawnej. W tym zakresie może być wykorzystywana porada świadczona przez paralegals, nieprawników, doświadczonych w udzielaniu wsparcia w dziedzinach takich, jak: zadłużenia, zatrudnienie i świadczenia społeczne, które są domeną poradnictwa obywatelskiego (druk sejm. nr 1868, kadencja VIII Sejmu RP). Jeśli składową problemu jest bardziej złożona kwestia prawna, możliwa jest również bliska współpraca doradcy obywatelskiego z radcami prawnymi i adwokatami, co przełoży się na bardziej kompleksowe potraktowanie sprawy i rozwiązanie problemu, również dzięki wiedzy doradców o realiach systemów wsparcia publicznego w danej społeczności.

W dalszej części artykułu, dla uproszczenia, oba wymienione typy poradnictwa prawnego i obywatelskiego będą ujmowane łącznie jako ogółem „porady” lub „poradnictwo”, z wyłączeniem odrębnych typów poradnictwa, jak psychologiczne, pedagogiczne i wiele innych, o których nie traktuje niniejsza publikacja. Analizując w niniejszej pracy usługi 
poradnictwa dostępne dla osób z niepełnosprawnością o zróżnicowanym statusie majątkowym pominę usługi komercyjne, a skupię się na poradach publicznych.

W Polsce darmowa pomoc prawna skierowana do wąskiej grupy najuboższych obywateli, została wprowadzona stosunkowo niedawno, z początkiem roku 2016. Natomiast od stycznia 2019 r. poszerzone przepisy ustawy z 5 sierpnia 2015 r. o nieodpłatnej pomocy prawnej, nieodpłatnym poradnictwie obywatelskim oraz edukacji prawnej stanowią o dostępności darmowych usług w postaci: poradnictwa prawnego na etapie pozasądowym, świadczonego przez absolwentów prawa, radców prawnych i adwokatów, poradnictwa obywatelskiego, udzielanego przez doradców obywatelskich (ang. paralegals), a także mediacji, świadczonej przez mediatorów różnych zawodów, niekoniecznie prawników. Obecnie nieodpłatne poradnictwo obywatelskie i prawne, a także mediacja jako składowa obu usług w myśl przywołanych regulacji jest świadczona osobom, które nie są w stanie ponieść kosztów nieodpłatnej pomocy prawnej.

Punkty finansowane przez Skarb Państwa są organizowane w każdym powiecie, pod znanymi mieszkańcom adresami, w lokalach udostępnianych także przez poszczególne gminy.

\section{PORADY DLA OSÓB Z NIEPEŁNOSPRAWNOŚCIĄ - PROTOTYP USŁUG ZDALNYCH NA CZAS PANDEMII}

Poszerzenie przepisów o poradnictwie publicznym objęło również uzupełnienie regulacji o dostępność wirtualnych usług poradniczych. Od 1 stycznia 2019 r, „za pośrednictwem środków porozumiewania się na odległość" rozpoczęto świadczenie obu podstawowych rodzajów nieodpłatnych porad, prawnych i obywatelskich. Ta szczególna forma została skierowana do osób „ze znaczną niepełnosprawnością ruchową, które nie mogą stawić się w punkcie osobiście lub dotkniętych trudnościami w komunikowaniu się, o których mowa w ustawie z dnia 19 sierpnia 2011 r. o języku migowym innych środkach komunikowania się" (ustawa z dnia 5 sierpnia 2015 r., art. 8 ust. 8; Dz.U. z 2017. poz. 1824). Przepisy wykonawcze wskazują zróżnicowane formy udzielania porad na odległość: telefonicznie, pocztą elektroniczną, przez komunikator internetowy, w formie wideorozmowy (Rozporząazenie Ministra Sprawiedliwości z dnia 21 grudnia 2018 r., pkt 20 Załącznika nr 2). Ponadto dla osób z niepełnosprawnościami przewidziano możliwość organizowania poradnictwa wyjazdowego poza lokalem punktu, stosownie do zgłoszonych potrzeb.

Jak wynika z określenia adresatów oferty, przyjętym kryterium dla udzielenia porad w szczególnej formie nie była ustawowa definicja osoby niepełnosprawnej, ale celowościowe ujęcie grupy, związane $\mathrm{z}$ trudnościami w dostępie do usług. W ten sposób trudności te mogą mieć również charakter przejściowy i nie wiążą się z orzekaniem o niepełnosprawności, jak przykładowo osoby okresowo niesprawne po wypadku i w trakcie rehabilitacji. Zatem oferta poradnictwa wirtualnego i we wszystkich innych formach świadczenia na odległość w okresie przez pandemią z jednej strony została skierowana do 
grupy poszerzonej, bo niekoniecznie posiadających orzeczenie (Giełda, 2015), a z drugiej strony nieco zawężona do osób borykających się z niepełnosprawnościami dwóch typów wskazanych w ustawie: trudności w poruszaniu się oraz w komunikowaniu się.

W 2019 r. powiaty wdrażając regulacje o szczególnych formach porad, były zobowiązane do dostosowania organizacji porad do zapewnienia wskazanej grupie dogodniejszych form poradnictwa, jak również prostego dopełniania formalności wstępnych związanych $\mathrm{z}$ dostępem do usługi. Co do zasady - darmowe porady zgodnie z przyjętymi regulacjami są udzielane osobie, która złoży pisemne oświadczenie, że nie jest w stanie ponieść kosztów odpłatnej pomocy prawnej. Dla omawianej grupy przewidziano przesyłanie i odbiór tych oświadczeń również na odległość w momencie zapisywania się na poradę lub dostarczenie oświadczenia inną drogą do starostwa powiatowego.

Zatem do nastania epidemii Covid-19 procedury obejmujące porady w szczególnych formach, dedykowane osobom z szeroko rozumianą niepełnosprawnością, funkcjonowały już kilkanaście miesięcy, a ich zastosowanie było testowane w praktyce. Dodatkowo w tym okresie powinny zostać objęte działaniami sprawdzającymi ze strony wojewodów nadzorujących wykonywanie zadań zleconych z zakresu administracji rządowej. Po upływie ponad roku działał pierwszy model wirtualnych usług poradniczych skierowany do osób z niepełnosprawnością, włączając w to procedury, obieg informacji i dokumentów.

$\mathrm{Z}$ tego względu w chwili nastania pandemii prototypem dla poradnictwa stał się właśnie szczególny tryb obejmujący porady wirtualne dla osób z niepełnosprawnością. Od marca 2019 r. starostwa powiatowe, podejmując działania mające na celu zapobieganie rozprzestrzeniania się wirusa Covid-19, w znakomitej większości odwołały wizyty osobiste w punktach porad. W pierwszych dniach pandemii wskazywały na procedurę poradnictwa zdalnego jako obowiązującą przy zasięganiu porad przez wszystkich mieszkańców, posiłkując się ogólnymi przepisami o szczególnych regulacjach kryzysowych, tzw. pierwszej tarczy Covid-19, gdyż szczególne regulacje dotyczące poradnictwa nie zostały jeszcze dostosowane do ograniczeń pandemicznych.

Tym samym w zasadzie „od ręki” zapewniono powszechny dostęp do porad w formie zdalnej. Rozwiązanie to było o tyle korzystne, że nawet w pierwszym okresie nagłego lockdownu w marcu i kwietniu 2020 r. nie pozbawiało obywateli, wystarczająco zdezorientowanych sytuacją, potencjalnego dostępu do usług poradniczych. Tym samym zachowano dostępność dodatkowego kanału przekazywania informacji o nowych regulacjach związanych z funkcjonowaniem rozmaitych dziedzin życia i gospodarki w okresie epidemii.

Taki sposób zapewnienia ciągłości poradnictwa wobec ograniczeń epidemicznych sugerował przejściowo w pierwszej połowie marca resort sprawiedliwości (Komunikat w związku z zagrożeniem COVID-19, https://darmowapomocprawna.ms.gov.pl/pl/aktualnosci, dostęp: 31.01.2021). Natomiast samą treść szczególnych regulacji o poradnictwie dostosowano dopiero dwa miesiące później w następstwie pierwszych działań, polegających na faktycznym wdrożeniu procedur dla osób z niepełnosprawnością do korzystania przez wszystkich beneficjentów. Opcję świadczenia porad zdalnych włączono do przepisów o poradnictwie prawnym i obywatelskim wraz z przyjęciem kolejnych regulacji dotyczących epidemii Covid-19, wprowadzając wyjątek polegający na możliwości udzie- 
lania wszystkim obywatelom porad „w czasie zagrożenia epidemicznego, w okresie stanu epidemii albo stanu nadzwyczajnego" także za pośrednictwem środków porozumiewania się na odległość (ustawa z dnia 5 sierpnia 2015 r., art. 28a). Wówczas uproszczono również wymogi kwalifikujące do otrzymania porady przez zniesienie wymogu składania oświadczenia o niemożności poniesienia kosztów komercyjnej pomocy prawnej ${ }^{2}$. To z kolei w czasie pandemii stanowiło znaczne udogodnienie dla wszystkich, którzy teraz mieli nie pojawiać się osobiście w lokalach punktów porad, również dla osób z niepełnosprawnością.

\section{OGRANICZENIE FORM ŚWIADCZENIA PORAD A ROLA USŁUGI}

Mimo, że regulacje dostosowujące przepisy o poradnictwie prawnym i obywatelskim do przedłużającej się sytuacji pandemii uprawniały do świadczenia usług w obu formach - zarówno osobistej, jak i zdalnej, to w wielu miejscowościach już nie wznowiono później usług osobistych nawet w okresie zmniejszonego ryzyka zachorowań. Podobnie jak przed pandemią w gestii samorządów pozostała organizacja poradnictwa prawnego i obywatelskiego na terenie powiatu. Zatem starostwa były uprawnione do wskazania tylko jednej z form poradnictwa i wydania lokalnych rozstrzygnięć, jak przykładowy komunikat urzędu m.st. Warszawy, który obowiązywał w niezmienionej formie co najmniej aż do początku roku 2021: „W związku z przeciwdziałaniem zagrożeniom związanym z COVID-19, o których mowa w art. 1 i 2 ustawy z dnia 2 marca 2020 r. o szczególnych rozwiązaniach związanych z zapobieganiem, przeciwdziałaniem i zwalczaniem COVID-19, innych chorób zakaźnych oraz wywołanych nimi sytuacji kryzysowych (Dz. U. z 2020 r. poz. 374) oraz ogłoszeniem stanu epidemii na terenie kraju informujemy, że od dnia 16 marca 2020 r. do odwołania zawieszona zostaje na terenie m.st. Warszawy stacjonarna działalność punktów nieodpłatnej pomocy prawnej i nieodpłatnego poradnictwa obywatelskiego. Obsługa klientów w punktach, także w zakresie nieodpłatnej mediacji, nie będzie świadczona" (Komunikat o działalności punktów nieodpłatnej pomocy prawnej i nieodpłatnego poradnictwa obywatelskiego na terenie m.st. Warszawy, https://warszawa19115.pl/-/komunikat, dostęp: 1.12.2020 r.).

Nie rozstrzygając, czy decyzje tego typu były proporcjonalne do faktycznego zagrożenia epidemicznego w związku ze zróżnicowanym ryzykiem zachorowań w poszczególnych okresach roku 2020, należy stwierdzić, że ubogo wypada porównanie spektrum form otrzymywania porad przez osoby z niepełnosprawnościami w epidemii oraz przed podjęciem przez samorządy podobnych decyzji o wykluczeniu wszelkich spotkań osobistych. Wcześniej grupa ta miała możliwość skorzystania z poradnictwa telefonicznie i przez internet, przy czym było to kwestią wyboru najdogodniejszej formy według

\footnotetext{
${ }^{2}$ Zniesienie przepisu dotyczyło jedynie formalności składania oświadczenia w tej materii. Nie zrezygnowano natomiast $\mathrm{z}$ samego kryterium dopuszczającego do otrzymania porad, tj. nadal są to osoby, które nie mogą sobie pozwolić na poniesienie kosztów komercyjnej porady prawnej.
} 
uznania i stosownie do potrzeb. Jednocześnie powiaty były zobligowane do zapewnienia lokalizacji punktów w miejscach dostępnych dla osób poruszających się na wózkach inwalidzkich, by umożliwić osobiste przedstawienie sprawy prawnikowi lub doradcy obywatelskiemu. Dzięki dopuszczeniu spotkań poza stałymi lokalami punktów organizowane były także wizyty domowe, pomocne dla osób obłożenie chorych, które nie decydowały się zasięgać porady przez pełnomocnika lub nie miały możliwości upełnomocnić zaufanej osoby. Spotkania mogły się odbywać także w innych miejscach aktualnego pobytu, jak dom opieki lub miejsce odbywania rehabilitacji. Inną opcją było umówienie spotkania w lokalu ze specjalistycznym sprzętem wspomagającym komunikację z osobami z dysfunkcją mowy słuchu lub wzroku albo w obecności tłumacza języka migowego. Porady w sprawach wymagających kilkukrotnego kontaktu mogły przebiegać w formie mieszanej, częściowo zdalnie, co było dla wszystkich zainteresowanych znacznym udogodnieniem. Dostarczanie prawnikowi lub doradcy wymaganych informacji mogło odbyć się telefonicznie, a w miejsce kolejnego spotkania zgromadzone w międzyczasie dokumenty mogły być przekazane pocztą elektroniczną. Tą samą drogą radca prawny lub adwokat miał możliwość przesłać interesantowi przygotowany projekt pisma, niezbędnego w celu załatwienia omawianej sprawy.

W związku z ograniczeniem form udzielania porad w okresie pandemii warto zadać pytania o wpływ świadczenia usługi w sposób zdalny na jej jakość i na stopień zaspokojenia potrzeb osób z niepełnosprawnością. Można przyjąć, że osiągnięcie założonego celu usług zachodzi, jeśli zmiana metod kontaktu pomiędzy wykonawcą usługi a osobą z niepełnosprawnością nie powoduje zubożenia jakości relacji poradniczej w aspekcie wzajemnego porozumienia beneficjenta i świadczeniodawcy, tak aby ten drugi możliwie najpełniej zrozumiał sytuację beneficjenta i w ślad za tym mógł opracować adekwatne rozwiązania, a beneficjent otrzymaną poradę zrozumiał i zaakceptował, co w końcu jest niezbędnym warunkiem późniejszego skutecznego wcielenia jej w życie.

Naturalnie istnieją także inne kluczowe parametry decydujące, że dana usługa jest teoretycznie jest dostępna, jednak świadczona w taki sposób, że realnie nie odpowiada na problem beneficjenta i przez to nie stanowi dla niego rzeczywistego wsparcia. Należy jednak przyjąć, że inne parametry, jak choćby jakość merytoryczna porad w zakresie wynikającym z poziomu kwalifikacji osób ich udzielających, nie zmienia się wraz z formą udzielania porad. Podobnie inne kwestie organizacyjne, które przekładają się w jakimś stopniu na poziom motywacji wykonawców, nie zależą od form świadczenia usługi. Założenie takie jest uprawnione, gdyż w okresie pandemii nie zmieniały się ani prawne, ani organizacyjne wytyczne związane z rozliczaniem i premiowaniem wykonawców usługi, ani wymogi związane $\mathrm{z}$ dokumentowaniem ich pracy.

\section{POMIĘDZY IDEAŁEM SPRAWIEDLIWOŚCI A SYTUACJĄ OSOBISTĄ}

Dostęp do sprawiedliwości czy do prawa postrzegany jest jako instrument wsparcia praw i wolności człowieka i jako taki zapisany w wielu dokumentach konstytuujących zasady funkcjonowania w Polsce i za granicą (Izdebski, 2008). Jednak pomiędzy ideałem zapew- 
nienia praw i obowiązków przysługujących każdemu obywatelowi opisanych w systemie prawa a realną sytuacją tego obywatela istnieje duża przestrzeń. Z punktu widzenia podmiotu tych praw i obowiązków jest ona niekiedy postrzegana wręcz jako otchłań. Nie chodzi tu o bezradność i nieadekwatność norm prawnych do rzeczywistych wydarzeń życiowych (wówczas za stratę czasu można uważać analizy poradnictwa prawnego!). Akcentuję raczej fakt, że nie każde spotkanie osoby z systemem instytucji i norm prawnych okazuje się skuteczne i pożyteczne dla poprowadzenia jej spraw. Od czego więc zależy, aby jednak takim właśnie było?

By instytucja prawna - w naszym przypadku porada udzielana na etapie przedsądowym albo pozasądowym - mogła sprostać ambitnemu zadaniu ochrony praw i wolności człowieka stosownie do jego potrzeb, konieczne jest jak najbliższe „spotkanie” instytucji systemu prawnego i regulacji z konkretną sytuacją osobistą i jej kontekstem. W praktyce dostępu do prawa jest wiele barier dla bliskiego spotkania tych dwóch rzeczywistości. Niektóre z nich wiążą się z właściwościami instytucji prawa i sposobu posługiwania się nim przez wykonawców usług, a inne przeszkody wynikają z mimowolnych zachowań samych beneficjentów, mimo że oczekują oni pomocy zindywidualizowanej, dostosowanej do potrzeb.

Wreszcie niektóre z przeszkód dla zbliżenia prawa do sytuacji osobistej są charakterystyczne dla efektywności świadczenia usług społecznych w ogóle, niekoniecznie usług prawniczych lub pokrewnych, jak np. poziom zaufania, który uda się wytworzyć w toku obopólnej współpracy beneficjenta i świadczeniodawcy. M. Racław (2015, s. 320) analizując przykład opieki zauważa, że jakość usług społecznych wytwarza się w wyniku kontaktów osobowych. Tutaj jest podobnie, przybliżenie możliwości systemu prawnego z potrzebami klienta wynika z relacji świadczeniodawcy i beneficjenta. Po obu stronach aktorów tej relacji będą bariery.

Warto przyjrzeć się im bliżej na podstawie ważnego etapu poradnictwa, dotyczącego w zasadzie każdej sprawy zgłoszonej do porady prawnej czy obywatelskiej, to jest diagnozy zgłaszanego problemu, a w ujęciu prawniczym - fazy ustalania stanu faktycznego.

\section{WARUNKI PRZYBLIŻENIA SYSTEMU PRAWNEGO DO SYTUACJI OSOBISTEJ - ŚWIADCZENIODAWCA}

Wśród barier, które potencjalnie mogą wystąpić do strony świadczeniodawcy, wiele może wynikać z hermetyczności języka prawniczego (por. Winczorek, 2015). Jest ona cechą większości terminów specjalistycznych, przy czym hermetyczność języka prawniczego jest dodatkowo związana w dużym stopniu z nieprzystawaniem świata pojęć prawnych jako wystandaryzowanych, zatem z konieczności ogólnych, do świata osobistych przeżyć, zawsze indywidualnych. Zetknięcie się z terminami prawniczymi bywa stresujące dla beneficjentów przez samą obcość, a niekiedy nawet przez nieintuicyjne dosłowne brzmienie słów. Jako przykład niech posłużą terminy, używane przez prawnika w obcobrzmiącym kontekście, stosowane odmiennie, aniżeli w języku potocznym, na przykład sformułowanie „zabezpieczenie upada”, które przecież nie oznacza zawsze 
braku możliwości wnioskowania o jego przedłużenie, czy też skarga „uznana została za niedopuszczalną", czego słuchacz nie obeznany z językiem prawnym nie zinterpretuje pozytywnie, pomimo iż istnieje prawdopodobieństwo, że sprawę można zgłosić innemu, po prostu właściwemu kompetencyjnie podmiotowi. W takich sytuacjach bezpośredni kontakt i obserwacja mowy ciała beneficjenta w procesie udzielania porady są nieodzowne, gdyż osoba onieśmielona własnym niezrozumieniem terminów prawniczych może nie werbalizować dezorientacji czy niepokoju, ale sygnalizować jedynie pośrednio. Dostrzeżenie takiej sytuacji może być dla prawnika jedynym sygnałem, że jego objaśnienia nie są zrozumiałe, a udzielone porady mogą nie zostać podjęte, a nadto konieczne jest przerwanie monologu świadczeniodawcy i podjęcie innej próby porozumienia się.

Nawet przy możliwości bezpośredniej obserwacji mowy ciała dostrzeżenie u beneficjenta niezrozumienia czy niepokoju wymaga określonych kompetencji od świadczeniodawcy. Dlatego przy poradzie mailowej, przez telefon, przez komunikator internetowy, ale bez możliwości wideorozmowy, na podstawie samej intonacji głosu może być to znacznie utrudnione lub w ogóle niemożliwe. Szczególnie w sytuacji, gdy beneficjent nie wyartykułuje tego wprost ze względu na onieśmielenie albo przez zwyczajną nieświadomość, może narastać niezrozumienie co do istoty problemu, skutkujące nietrafną diagnozą jego sedna, czego rezultatem jest nieadekwatność porady.

Inną ważną kompetencją, której brak u świadczeniobiorcy może być barierą dla porozumienia na rzecz trafnej diagnozy, jest umiejętność dostrzeżenia kontekstu i pozaprawnych elementów problemu, które towarzyszą znakomitej większości spraw. Zwraca na to uwagę J. Winczorek, powołując się na ustalenia badaczy z krajów, gdzie systemy poradnictwa publicznego mają dłuższą ugruntowaną tradycję (Winczorek, 2015, s. 32-33, 48). Zidentyfikowanie szerszego kontekstu problemu wpłynie nie tylko na dobór pomocnych instytucji prawnych, ale i właściwe określenie sposobu dalszej pracy poradniczej. Dla sukcesu przy rozwiązywaniu problemów złożonych z wątków prawnych i pozaprawnych konieczne może być włączenie wsparcia specjalistów z innych dziedzin. W takim wypadku całościowa porada prawa będzie dotyczyć wskazania - często wśród instytucji funkcjonujących na podstawie regulacji szczególnych - sposobu uzyskania wsparcia, które może być niezbędne jako komplementarne do działań prawnych albo nawet warunkować skuteczność działań prawnych. Współpraca z innymi specjalistami w procesie poradniczym może być niezbędna również z formalnego punktu widzenia, by zweryfikować i pozyskać profesjonalną i wiarygodną dokumentację okoliczności, z którymi boryka się beneficjent. Identyfikacja pozaprawnych aspektów sprawy jest ważna nie tylko przy poradach złożonych i wieloetapowych.

Bywa również, że beneficjent zgłasza się po poradę niejako z gotowym żądaniem stawionym świadczeniodawcy. Przykładowo, osoba chciałaby zwiększyć stawkę świadczenia opiekuńczego, aby przysługiwała jej kwota w wysokości świadczenia otrzymywanego przez znajomą, która opiekuje się niepełnosprawnym dzieckiem. W toku rozmowy może okazać się, że beneficjentka od lat zajmuje się swoją leżącą matką i w tym wypadku świadczenie nie może być podwyższone. Jednak umiejętna rozmowa doprowadzi do szerszego naświetlenia sytuacji rodzinnej i przyznania przez beneficjentkę, że obecnie żyją z matką 
na granicy ubóstwa w związku z koniecznością rezygnacji z pracy zawodowej na rzecz opieki. Uzyskanie pełniejszej wiedzy o sytuacji rodziny, nawet w przypadku niemożności udzielenia pomocy zgodnie z oczekiwaniem beneficjenta, pozwoli na wskazanie innych możliwości wsparcia, ale także udzielenia zachęty do skorzystania z nich. Bowiem osoby, których sytuacja finansowa wcześniej była stabilniejsza, mogą miec różnego typu obiekcje. Na przykład związane z poczuciem stygmatyzacji, gdyby stali się klientami systemu pomocy społecznej. Mogą też uważać, że z ich strony pobieranie świadczeń byłby nadużyciem albo po prostu nie posiadają wiedzy, że są istnieją formy pomocy finansowej skierowane do niższej klasy średniej, a przynajmniej niewymagające spełniania rygorystycznych kryteriów socjalnych. Dzięki dostrzeżeniu na etapie diagnozy złożoności sytuacji, w tym przypadku aspektów finansowych i bytowych, możliwe jest opracowanie metod wsparcia beneficjentów, zanim powstanie cały klaster problemów, np. tzw. spirala zadłużenia wywołana koniecznością zaciągnięcia niekorzystnych pożyczek finansowych, tzw. chwilówki (Arcimowicz, 2018). Kompetencja polegająca na dostrzeżeniu pozaprawnych i kontekstowych elementów problemu jest uwypuklana w procesie kształcenia doradców obywatelskich ze względu na istotę poradnictwa obywatelskiego, które specjalizuje się w sprawach złożonych $\mathrm{z}$ aspektów pozaprawnych.

\section{WARUNKI PRZYBLIŻENIA SYTUACJI OSOBISTEJ DO SYSTEMU PRAWNEGO - BENEFICJENT}

Natomiast wśród barier, które potencjalnie mogą występować po stronie beneficjentów, należy wspomnieć o zjawisku oczywistym w przypadku konieczności osobistego przedstawiania własnych problemów, o emocjonalnym stosunku do sprawy. Będzie on skutkował subiektywną diagnozą sedna własnego problemu życiowego i prawnego. Ponadto, jak wskazuje znawczyni dziedziny A. Kargulowa, niekiedy powoduje niechęć do przekazania kompletu okoliczności albo trudności wskazaniem tych istotnych (Kargulowa, 2005). W niektórych przypadkach może wiązać się z celowym - albo z drugiej strony zupełnie nieświadomym - wskazywaniem zastępczych celów zgłoszenia się po poradę. Można to zobrazować przypadkiem, gdy osoba na wstępie kontaktu deklaruje chęć uzyskania wsparcia w uzyskaniu mieszkania komunalnego dla dorastających dzieci, nie ujawniając, że sednem problemu jest wieloletnia przemoc stosowana przez jej męża wobec członków rodziny. Brak przedstawienia tego zagadnienia może skutkować błędną, bo niepełną poradą, na przykład dotyczącą jedynie ogólnych zasad przydziału wsparcia mieszkaniowego, które jednak nie będzie przysługiwało na rzecz osób ze średnim uposażeniem. Po dostrzeżeniu potrzeby zidentyfikowania (pozornie pozaprawnych) dodatkowych aspektów sprawy świadczeniodawca podczas spotkania powinien zastosować komunikaty otwierające rozmowę o istocie problemu lub zadać beneficjentowi odpowiednio taktowne pytania. Gdy świadczeniodawcy uda się „przedostać” przez barierę emocjonalną wstydu lub zastraszenia wiążącego się ze zjawiskiem przemocy domowej, na dalszym etapie procesu poradniczego może okazać się, że - pod warunkiem adresowania rozwiązań do problemu węzłowego - znajdzie się szybsza prawna ścieżka wsparcia 
(na przykład przez eksmisję sprawcy), aniżeli ubieganie się przez ofiary przemocy o publiczne wsparcie mieszkaniowe, co może trwać wiele lat.

Inne zniekształcenia dla określenia stanu faktycznego mogą mieć miejsce, gdy beneficjent jest przekonany o zasadności przedstawienia całokształtu problemu, lecz będąc pod wpływem emocji nie umie tego uczynić, wydarzenia i dokumenty prezentuje chaotycznie i wybiórczo. W takich wypadkach ustalenie faktów będzie możliwe jedynie po wglądzie w dokumentację przez świadczeniodawcę, co będzie niemożliwe przy wielu formach świadczenia poradnictwa na odległość. Na przykład przy kontakcie ograniczonym do rozmowy telefonicznej trudne będzie sformułowanie w pełni trafnej porady, jeśli kluczowe dokumenty dla sprawy będą czytane, a już wyjątkowo problematyczne może być przy obszerniejszych dokumentach, jak uzasadnienie orzeczenia sądowego, a także niemożliwe dla osób z niektórymi dysfunkcjami aparatu mowy. Dlatego przewagę w usuwaniu tej bariery będą miały wszelkie formy wirtualne zakładające możliwość udostępnienia kompletnej dokumentacji w formie elektronicznej.

Warto podkreślić, że bariery dla rzeczowego opisania problemu, związane z emocjonalnym stosunkiem do własnej sprawy, mogą dotyczyć każdego beneficjenta bez względu na prezentowany poziomu intelektualny. Nawet osoby z najlepszym wykształceniem ze względów emocjonalnych nie są w stanie bez pomocy niekiedy naświetlić trudnych okoliczności, które są konieczne do sformułowania kompetentnej i adekwatnej porady. Ponadto sam beneficjent może nie rozumieć znaczenia faktów czy dokumentów dla swej sprawy i co za tym idzie, ich nie przedłożyć.

Wiąże się to z podnoszoną kolejną barierą, jaką niewątpliwie mogą stanowić ograniczenia poznawcze (Winczorek, 2015) lub niski kapitał kulturowy (Sztandar-Sztanderska, 2018). Okoliczności takie mogą istotnie wpłynąć na rzetelność diagnozy, a następnie na poprawność udzielonej porady, szczególnie gdy świadczeniobiorca ograniczeń takich nie spostrzeże. Dopiero bezpośrednia dłuższa osobista rozmowa jest w stanie na przykład ukazać doradcy, że ktoś boryka się z ograniczeniami intelektualnymi.

Szczególnym przypadkiem będzie porada dla beneficjenta $\mathrm{z}$ niepełnosprawnością umysłową w stopniu lekkim, gdzie brak osobistego kontaktu może utrudnić dostrzeżenie, że ktoś boryka się z tym problemem. Wiele osób o niepełnosprawności tego typu dobrze radzi sobie z zaspokajaniem bieżących potrzeb, ale nie jest w stanie zauważyć długofalowych konsekwencji działań czy zaniechań. Świadczeniodawca poza dostosowaniem rozmowy i metod ustalania stanu faktycznego może również, mając na uwadze pomyślne wdrożenie udzielonej porady, zaproponować beneficjentowi tzw. asystę poradniczą. Na marginesie warto wskazać, że tego typu wsparcie jest praktykowane od dawna przez poradnicze organizacje pozarządowe (Bartnik, Kowalska, 2019), a w myśl obowiązujących przepisów asysta może być oferowana osobom z szeroko rozumianymi niepełnosprawnościami, a także osobom nieporadnym, w punktach porad prowadzonych przez podmioty trzeciego sektora. 


\section{JAKOŚĆ SPOŁECZNA USŁUG PORADNICZYCH DLA OSÓB Z NIEPEŁNOSPRAWNOŚCIĄ A FORMA ŚWIADCZENIA}

Skoro bliskie spotkanie instytucji systemu prawnego z konkretną sytuacją osobistą jest niezbędne dla świadczenia skutecznego poradnictwa, warto wyciągnąć wnioski dotyczące form organizacyjnych, przy których możliwe jest zniwelowanie opisanych barier, a tym samym uprawdopodobnienie należytej jakości społecznej usług poradniczych dla osób z niepełnosprawnościami.

Jak przytaczano wcześniej, koncepcja jakości społecznej usług bazuje na założeniu, że jest to wartość „wytwarzana w wyniku międzyosobowych kontaktów” (Racław, 2015, s. 320). Zatem klucz do kształtowania tych relacji w dużej mierze leży w rękach aktorów procesu poradniczego. Jak w przypadku innych usług społecznych szczególnie waży tutaj podejście świadczeniodawców, gdyż mają oni instytucjonalne umocowanie do bycia profesjonalnym gospodarzem procesu poradniczego. Po pierwsze, od sposobu ich pracy w dużej mierze zależeć będzie, czy beneficjent zdecyduje się obdarzyć ich zaufaniem. Od wytworzenia zaufanej relacji zależy, na ile trafnie zostaną określone potrzeby beneficjenta, czy świadczeniodawca przedstawi się beneficjentowi na tyle wiarygodny w zamiarze wsparcia go, że ten zdecyduje się udostępnić pełną dokumentację, której sam nie jest w stanie rzeczowo zaprezentować. Od profesjonalizmu osądu i zachowania świadczeniodawcy podczas kontaktu zależy, czy beneficjent podejmie próbę zniwelowania własnych ograniczeń - podzieli się kompletem danych o sprawie, również okolicznościami, które wiążą się z trudnymi przeżyciami emocjonalnymi, a mogą mieć kluczowe znaczenie dla kształtu wypracowanych rozwiązań. Wszystkie te aspekty przełożą się następnie na satysfakcję z usług poradniczych, gdyż wpływają na efekt końcowy, to jest na ile adekwatnie zostanie sformułowana porada końcowa, czy zostanie podjęta i z jakim skutkiem zostanie wdrożona.

Wiele $\mathrm{z}$ opisanych aspektów może być $\mathrm{w}$ pełni realizowanych podczas bezpośrednich kontaktów międzyludzkich. Nasuwa się więc, że dla zachowania wysokiej jakości społecznej usług poradniczych najkorzystniejsze jest poradnictwo, gdy ma miejsce osobiste spotkanie beneficjentów ze świadczeniodawcami. Niekiedy takie formy poradnictwa są czasowo wykluczone, a w przypadku niektórych niepełnosprawności niemożliwie również w dłuższej perspektywie. Tym bardziej warto zastanowić się, które formy zdalnego poradnictwa dają szansę bliskiego odwzorowania ideału bezpośredniego spotkania. Spośród zalet kontaktów osobistych należałoby w formach zdalnych odtworzyć co najmniej następujące możliwości: wytwarzanie zaufania poprzez przekonanie beneficjenta odnośnie intencji udzielenia mu pomocy, szansa obserwacji poziomu zrozumienia omawianych zagadnień a także stanu emocjonalnego beneficjenta, $w$ tym na podstawie sygnałów mowy ciała, oraz w miarę potrzeb udostępnianie świadczeniodawcy kompletu informacji i dokumentacji sprawy.

Zwłaszcza te dwa ostatnie wymogi - obserwacji beneficjenta przez świadczeniobiorcę i praca na wspólnych dokumentach mogą być najpełniej jednocześnie realizowane przy udzielaniu porad za pośrednictwem komunikatorów internetowych z możliwością wideorozmowy i sprawnego udostępniania dokumentów w postaci elektronicznej. Dlatego 
tę formę uznać można za jedyną ekwiwalentną do wymogów dla należytej jakości usług poradniczych.

Tymczasem dane resortu sprawiedliwości o zastosowaniu szczególnych form udzielania poradnictwa prawnego i obywatelskiego, udostępnione za okres od 13 maja do 31 listopada 2020 r. pokazują, że forma telefoniczna była stosowana w blisko $96 \%$ wszystkich porad zdalnych, porady pocztą elektroniczną udzielone zostały w blisko 4\% przypadków, a łącznie kontakt przez komunikator internetowy i $\mathrm{w}$ formie wideorozmowy podjęto w tylko 0,17\% przypadków (www.np.ms.gov.pl, dostęp na dzień 1.12.20). Wynika z tego, że najczęściej wybierane są formy, które w najmniejszym stopniu gwarantują zachowanie jakości społecznej poradnictwa, co, jak próbowano wykazać, znacząco oddziałuje na trafność, kompletność i skuteczność udzielanych porad.

Wydaje się, że tak niski wynik dla używania w poradnictwie aplikacji internetowych do prowadzenia wideorozmowy nie może być tłumaczony jedynie faktem, że nie każdy beneficjent jest w posiadaniu odpowiedniego sprzętu i dostępu do sieci. Dlatego interesujące będą dane, że już w roku 2015, gdy tylko 33,8\% osób z niepełnosprawnościami deklarowało korzystanie z internetu, aż 60,3\% w tej grupie wykorzystywało internetowe narzędzia do komunikacji interpersonalnej (Żuchowska-Skiba, 2019).

Zestawienie powyższych danych prowadzi do następującego wniosku. Można przyjąć, że to nie po stronie osób z niepełnosprawnościami leży zasadnicza przyczyna niezwykle rzadkiego, incydentalnego podejmowania w poradnictwie zdalnym kontaktu w formie wideorozmów. Wynikałoby z tego, że starostwa powiatowe w ramach działań organizacyjnych poradnictwa zdalnego praktykują jedną lub dwie formy kontaktu z beneficjentami, pomimo że mogą poruszać się w pojemniejszym polu regulacyjnym. Obowiązujące przepisy dopuszczają bowiem szersze spektrum form, aniżeli telefonowanie i wymiana korespondencji pocztą elektroniczną, jednak nie wskazują one jednoznacznie preferowanych kanałów komunikacji. Pogłębionych analiz wymagałoby określenie, co jest przyczyną zawężania pola organizacyjnego w stosunku do pola regulacyjnego polegającego na ograniczaniu form komunikacji z poziomu działań powiatów w zakresie organizacji i upowszechniania usług poradniczych. Czy opisana tendencja jest wynikiem dążenia starostw do prostoty organizacyjnej w dostosowaniu kanałów komunikacji do technicznych możliwości telefonowania (posiadanej przez niemal wszystkich mieszańców powiatu), bez świadomości urzędników o wpływie takiego rodzaju komunikacji na jakość usług? Czy też świadczenie porad głównie przez telefon jest raczej wynikiem preferencji bezpośrednich świadczeniodawców, tj. prawników i doradców obywatelskich, sugerujących takie rozwiązania osobom odpowiedzialnym $\mathrm{w}$ powiecie? Ta grupa $\mathrm{z}$ racji swojego profesjonalnego przygotowania i doświadczenia posiada wiedzę, że rzetelne udzielenie pełnowartościowej, czyli zindywidualizowanej, porady wymaga bliższej znajomości stanu faktycznego, wynikającego z dokumentacji, której poznanie drogą telefoniczną jest znacząco utrudnione, a w pełni praktycznie niemożliwe. Profesjonaliści są świadomi, że bez możliwości przekazania bliższych danych o sprawie, porada może przyjąć znacznie węższy zakres, co w sprowadza ją raczej do zakresu właściwemu informacji prawnej, przez którą rozumie się usługę „polegającą na dostarczaniu (...) informacji o regulacjach prawnych (...)”. Aby zobrazować tę różnicę, należy przywołać też definicję porady 
prawnej. Polega ona „na opracowaniu i przekazaniu (...) rzetelnych, skonkretyzowanych i zindywidualizowanych zestawów informacji odnoszących się do przedstawionego (...) problemu prawnego oraz $\mathrm{w}$ razie potrzeby pomocy $\mathrm{w}$ jego rozwiązaniu do momentu wkroczenia sprawy na etap sądowy”, zaś porada obywatelska zakłada dodatkowo „sporządzenie wspólnie planu działania i pomoc w jego realizowaniu” (System nieodpłatnego poradnictwa prawnego i obywatelskiego w Polsce, 2013, s. 10).

W zależności od odpowiedzi na pytanie o przyczynę tak częstego stosowania w poradnictwie zdalnym komunikacji przez telefon, należałoby rozważyć, czy ważna zmiana jakościowa instytucji poradnictwa obecnie nie jest uwarunkowana polem regulacyjnym tej instytucji. Można założyć co najmniej dwa następujące negatywne oddziaływania na formy i jakość poradnictwa zdalnego. Naturalnie nasuwa się brak w ustawie preferowanej formy komunikacji przy prowadzeniu poradnictwa zdalnego, względnie brak procedur wskazujących na konieczność uprzedniego przekazania przez świadczeniobiorcę najważniejszych dokumentów na potrzeby lepszej orientacji przy późniejszej omawianiu sprawy. Inną istotną okolicznością może być fakt, że przepisy nie uzależniają w żaden sposób wysokości wynagrodzenia radców prawnych, adwokatów, a także wartości dotacji na wykonywanie zadań przekazywanej organizacjom pozarządowym od liczby i zakresu porad udzielonych przez te pomioty i osoby. Wynagrodzenie zależy jedynie od obecności świadczeniodawców, tj. ich „gotowości” podczas trwania dyżuru poradniczego, a nie jest w żaden sposób powiązane z liczbą osób przybyłych po poradę, ale przede wszystkim pracochłonnością poszczególnych porad. Oznacza to, że niezależnie od wysokiego udziału prostych informacji w całej liczbie usług, nawet przy udzieleniu znikomej liczby zindywidualizowanych porad, w tym z przygotowanymi projektami niezbędnych beneficjentowi projektów pism lub innych dokumentów, wysokość docelowych poborów świadczeniodawców nie zmniejsza się.

Z zaprezentowanych rozważań wynika również ważny wniosek dla kształtowania jakości instytucji poradnictwa w okresach bez zagrożenia epidemicznego: że przy skłonności do stosowania przez organizatorów i świadczeniodawców, co dotyczy też części beneficjentów, metod komunikacji zdalnej w praktyce ograniczonych do przekazywania jedynie głosu, promowanie świadczenia poradnictwa podczas osobistych spotkań jest podstawowym warunkiem zachowania jego jakości i tym samym wypełniania jego roli. Zatem warto utrzymać i promować wśród osób z niepełnosprawnościami możliwość wizyt domowych i spotkań w innych dogodnych dla nich miejscach, w pierwszym dostępnym terminie.

Ponadto nasuwa się optymistyczny wniosek. Otóż w przypadku występowania ograniczeń dla spotkań osobistych, jak te przeżywane w czasie epidemii, poradnictwo prawne czy obywatelskie może zachowywać wysoką jakość społeczną pod warunkiem większego upowszechnienia i wykorzystywania najpełniejszych narzędzi technicznych, jakie aktualnie przynosi wirtualizacja. Chodzi o takie formy porozumiewania się na odległość, które dają możliwość nie tylko przekazania dokumentacji, usłyszenia głosu, ale i ukazania twarzy ludzkiej w czasie rzeczywistym. Tego typu technika w wysokim stopniu odwzorowuje zalety spotkań międzyludzkich. W ten sposób rozważania o możliwościach zachowania odpowiedniej jakości społecznej usług poradniczych dla osób z niepełnosprawnościami 
i metodach zagwarantowania skutecznych porad doprowadziły do podobnych spostrzeżeń, jak odczucia wielu osób w czasie epidemii - do refleksji o niedocenianych wcześniej wartościach: osobistych spotkań i przywileju oglądania ludzkiej twarzy.

Autorka dziękuje Kindze Francuzik za podzielenie się swoimi doświadczeniami z zakresu poradnictwa prawnego. 


\section{BIBLIOGRAFIA}

Arcimowicz, J. (2018). Parabanki i pożyczki krótkoterminowe („chwilówki”) w dyskursie prasowym i w badaniach opinii publicznej. W: I. Jakubowska-Branicka (red.), Rynek Firm pożyczkowych w Polsce (s. 147-181). Polskie Towarzystwo Ekonomiczne.

Bartnik, A.S., Kowalska, K.J. (2019). Nieodpłatna pomoc prawna. Wolters Kluwer.

Giełda, M. (2015). Pojęcie niepełnosprawności. Prawnicza i Ekonomiczna Biblioteka Cyfrowa. Wydział Prawa, Administracji i Ekonomii Uniwersytetu Wrocławskiego. https://repozytorium.uni.wroc.pl/dlibra/publication/84855/edition/79842?language=pl

Instytut Spraw Publicznych (2013). Korzystający i niekorzystający z poradnictwa prawnego i obywatelskiego - raport cząstkowy. https://www.ekonomiaspoleczna.gov.pl/download/ files/PPIO/Raport_ISP_Beneficjenci_final_16_04_13.pdf

Izdebski, H. (2008). Elementy teorii i filozofii prawa. LexisNexis.

Kargulowa, A. (2005). O teorii i praktyce poradnictwa. Wydawnictwo Naukowe PWN.

Komunikat o działalności punktów nieodpłatnej pomocy prawnej i nieodpłatnego poradnictwa obywatelskiego na terenie m.st. Warszawy. https://warszawa19115.pl/-/komunikat

Komunikat w związku z zagrożeniem COVID-19. https://darmowapomocprawna.ms.gov. $\mathrm{pl} / \mathrm{pl} /$ aktualnosci

Konecki, K.T., Chomczyński, P. (red.) (2012). Słownik socjologii jakościowej. Difin SA.

Merton, R.K. (1968). The Matthew Effect in Science. The reward and communication systems of science are considered. Science, Vol 159 (3810), 56-63. https://science.sciencemag.org/content/159/3810

Racław, M. (2015). Kwestia opieki nad osobami starszymi a zaufanie społeczne. W: E. Giermanowska (red.), Kwestia społeczna u progu XXI wieku: ksiega jubileuszowa dla Profesor Józefiny Hrynkiewicz (s. 313-328). Wydawnictwo Uniwersytetu Warszawskiego.

System nieodpłatnego poradnictwa prawnego i obywatelskiego w Polsce. Propozycje rozwiazań modelowych i założeń polityki państwa (2013). Praca zbiorowa koordynowana przez INPRiS, ZWP MPiPS.

Sztandar-Sztanderska, K. (2018). Państwo na co dzień. Etnografia polityk publicznych wobec grup zmarginalizowanych we Francji. Kultura i Rozwój, 1(6)/2018, 10-25. https:// scholar.com.pl/pl/index.php?controller=attachment\&id_attachment=667

Winczorek, J. (2015). Przegląd literatury na temat dostępności i korzystania z pomocy prawnej. Instytut Prawa i Społeczeństwa.

Winczorek, J. (2019). Dostęp do prawa. Ujęcie socjologiczne. Wydawnictwo Naukowe Scholar.

Żuchowska-Skiba, D. (2019). Potencjał nowych technologii internetowych w pracy socjalnej z osobami z niepełnosprawnościami. Societas Communitas, 2(28)/2019, 243-258. http:// societas-communitas.isns.uw.edu.pl/numer-aktualny.php 


\section{AKTY PRAWNE I PROJEKTY}

Druk sejmowy nr 1868, kadencja VIII Sejmu RP, Uzasadnienie przedstawionego przez Prezydenta RP projektu ustawy o zmianie ustawy o zmianie ustawy z dnia 5 sierpnia 2015 roku o nieodpłatnej pomocy prawnej i edukacji prawnej oraz edukacji prawnej oraz niektórych innych ustaw.

Rozporządzenie Ministra Sprawiedliwości z dnia 21 grudnia 2018 roku w sprawie nieodpłatnej pomocy prawnej oraz nieodpłatnego poradnictwa obywatelskiego. Dz.U. 2018 poz. 2492.

Ustawa z dnia 15 sierpnia 2015 roku o nieodpłatnej pomocy prawnej, nieodpłatnym poradnictwie obywatelskim oraz edukacji prawnej. Dz.U. 2018 poz. 2492. 